\title{
ANALISIS PERLAKUAN AKUNTANSI AGRIKULTUR PADA PETANI KELAPA PADA DESA DI DAERAH LIKUPANG SELATAN : DAMPAK RENCANA PENERAPAN ED PSAK NO.69 TENTANG AGRIKULTUR
}

\author{
Claudia W.M. Korompis \\ email : wanda korompis@yahoo.co.id
}

\begin{abstract}
Biological assets is a unique asset, because of the transforming growth even after biological assets generate an output. Although it has many unique, but the financial management of biological assets still have to refer to the Financial Accounting Standards. Currently the Financial Accounting Standards Board (DSAK) issued SFAS No. ED 69 on agriculture which will come into force on 1 January 2017. According to this SFAS Biological assets are measured at initial recognition and at the end of each reporting period at fair value less costs to sell. Many of Regions, especially in the village do not know the accounting treatment for biological assets. This makes researchers want to analyze the impact of the application of IAS 69 ED is the continuation of agricultural farmers' efforts in this regard coconut trees in the village in the district South Likupang. With the proper financial management from the village, will support the country's economy as a whole, especially in the face of the MEA. This research uses descriptive analysis. The results of this study indicate that in general the village in the Regional South Likupang not apply to recognize the fair value of their assets. The traditional system by recognizing the asset at the acquisition price is still the basis in preparing the financial statements. But with this study are expected, farmers / entrepreneurs start applying SFAS palm plant began in 2017.
\end{abstract}

Keywords: Accounting, Agriculture, ED IAS 69, Village.

\subsection{Latar Belakang}

\section{PENDAHULUAN}

Indonesia merupakan Negara yang kaya dengan berbagai macam komoditas alam atau agrikultur. Sumber daya alam tersebut tumbuh dan berkembang dengan baik, ditunjang dengan keunggulan geografi Negara Indonesia. Peran produk agrikultur dalam peningkatan perekonomian Indonesia saat ini sangat baik. Hal tersebut membuat Indonesia dipandang sebagai Negara yang memiliki peluang pasar yang sangat potensial. Selain itu, Indonesia juga mulai diperhadapkan dengan era perekonomian baru yang disebut sebagai Masyarakat Ekonomi Asean (MEA) dengan konsekuensi semakin mudahnya setiap Negara di kawasan Asean untuk memasarkan produknya di Negara lain.

Berbagai kebijakan dan strategi penataan keuangan aset biologis harus dikelola dengan baik, mengingat persaingan yang semakin ketat dengan industri-industri yang sama dari luar Indonesia. Dengan adanya pengelolaan keuangan yang baik serta laporan keuangan yg berkualitas, dapat menjamin kelangsungan usaha perusahaan.

Pengelolaan keuangan aset biologis harus mengacu pada Standar Akuntansi Keuangan. Standar Akuntansi Keuangan sudah beberapa kali mengalami revisi karena dituntut harus sesuai dengan IFRS (International Financial Reporting Standards), mengingat perkembangan Global yang mengarah kepada perdagangan bebas Internasional dan memerlukan pelaporan keuangan yang tidak menyebabkan asimetri informasi di kalangan pengguna laporan keuangan.

Penyusunan laporan keuangan yang mengacu kepada IFRS menjadi tantangan bagi perusahaanperusahaan yang ada. Bagi perusahaan yang memiliki aset biologis, harus mengetahui perbedaan asetnya dengan aset non-biologis. Sebagai contoh dalam proses produksi, beberapa aset biologis yang dikembangbiakan dengan cara yang sama, tidak akan menghasilkan output/aset turunan yang sama. Sedangkan aset non-biologis dalam hal ini barang dalam proses, saat melalui proses yang sama, pasti akan menghasilkan output yang sama.

Farida (2013 : 2), menyatakan bahwa aset biologis adalah aset yang unik, karena mengalami transformasi pertumbuhan bahkan setelah aset biologis menghasilkan sebuah output. Transformasi yang 
terjadi pada aset biologis terdiri dari proses pertumbuhan, degenerasi, produksi dan prokreasi yang dapat menyebabkan berbagai perubahan secara kualitatif dan kuantitatif dalam kehidupan aset yang berupa tumbuhan atau hewan tersebut. Aset biologis dapat menghasilkan aset baru yang terwujud dalam agricultural produce atau berupa tambahan aset biologis dalam kelas yang sama. Adanya transformasi biologis pada aset biologis, maka diperlukan pengukuran yang dapat menunjukkan nilai dari aset tersebut secara wajar sesuai dengan kesepakatan dan kontribusinya dalam menghasilkan aliran keuntungan yang ekonomis bagi perusahaan.

Saat ini Dewan Standar Akuntansi Keuangan (DSAK) telah mengeluarkan ED PSAK No. 69 tentang agrikultur yang nantinya akan mulai berlaku pada 1 Januari 2017. Penerapan nilai wajar dalam akuntansi agrikultur membuat beberapa peneliti mengemukakan beberapa asumsi mereka. Herbohn dan Herbohn (2006) serta Dowling dan Godfrey (2001) menekankan pada meningkatnya volatilitas, manipulasi dan subyektifitas dari pendapatan yang dilaporkan dalam penerapan nilai wajar. Sedangkan Argiles dan Soft (2001) dapat menerima pengukuran menggunakan nilai wajar untuk aset biologis karena hal tersebut menghindari kompleksitas dalam menghitung biaya. Alokasi biaya tidak langsung juga merupakan salah satu sumber lain kompleksitas perhitungan biaya di pertanian. Kroll (1987) menyatakan bahwa kompleksitas dalam penilaian aset dengan menggunakan nilai historis merupakan suatu halangan utama dalam penilaian dengan basis nilai historis. Oleh karena itu, penilaian dengan menggunakan nilai wajar harus mempertimbangkan keseimbangan antara manfaat dan biayanya. Kemudahan (simplicity) dalam perhitungan merupakan keuntungan utama dalam menerapkan nilai wajar dibandingkan penggunaan nilai historis. Tetapi sampai saat ini belum ada kesepakatan dalam literatur-literatur sebelumnya dalam hal apakah terjadi volatilitas yang abnormal dalam pendapatan dan laba, relevansi nilai, perataan pendapatan (income smoothing) serta terjadi peningkatan atau penurunan profitabilitas akibat penerapan nilai wajar. (Maruli dan Mita, 2010 : 4-5)

Sulawesi Utara merupakan salah satu daerah yang memiliki produk agrikultur Kelapa terbesar di Indonesia khususnya Daerah Minahasa Utara. Oleh karena itu pelaporan keuangan yang lebih relevan dan informatif berdasarkan SAK sangat dibutuhkan untuk membantu perkembangan industri ini dalam menghadapi MEA. Petani Kelapa di Minahasa Utara khususnya di Daerah Likupang Selatan, sangat banyak, bahkan pertanian kelapa menjadi mata pencaharian utama masyarakat di Daerah ini. Peneliti hendak menganalisis dampak penerapan (studi pendahuluan) ED PSAK No.69 tentang Agrikultur dalam Standar Akuntansi Keuangan. Berdasarkan latar belakang, maka peneliti tertarik untuk mengambil judul "Analisis Perlakuan Akuntansi Agrikultur pada Petani Kelapa pada Desa di Daerah Likupang Selatan : Dampak rencana penerapan ED PSAK No.69 tentang Agrikultur “.

\subsection{Tujuan Penelitian}

Tujuan penelitian ini adalah untuk mengetahui dampak rencana penerapan ED PSAK No.69 tentang Agrikultur pada Pertanian Kelapa pada Desa di Daerah Likupang Selatan.

\section{TINJAUAN PUSTAKA}

\subsection{Aset}

Aset dalam Standar Akuntansi Entitas Tanpa Akuntan Publik paragraf 2:12 diartikan sebagai sumber daya yang dikuasai entitas sebagai akibat dari peristiwa masa lalu dan dari mana manfaat ekonomi di masa depan diharapkan akan diperoleh entitas. Dalam paragraf 2.14-2.16 menyatakan bahwa :

1. Manfaat ekonomi masa depan yang terwujud dalam aset adalah potensi dari aset tersebut untuk memberikan sumbangan, baik langsung maupun tidak langsung, terhadap aliran kas dan setara kas kepada entitas. Arus kas tersebut dapat terjadi melalui penggunaan aset atau pelepasan aset.

2. Beberapa aset, misalnya aset tetap memiliki bentuk fisik. Namun demikian bentuk fisik tersebut tidak esensial untuk menentukan eksistensi aset. Beberapa aset adalah tidak berwujud.

3. Dalam menentukan eksistensi aset, hak milik tidak esensial, misalnya properti yang diperoleh melalui sewa adalah aset jika entitas mengendalikan manfaat yang diharapkan mengalir dari properti tersebut. 


\subsection{Aset Biologis}

Aset biologis merupakan jenis aset berupa hewan dan tumbuhan hidup, seperti yang didefinisikan dalam IAS 41:

"Biological asset is a living animal or plant".

Dalam IAS 41, aset biologis didefinisikan sebagai tumbuh-tumbuhan dan hewan-hewan yang hidup yang dikendalikan atau dikuasai oleh perusahaan sebagai akibat dari kejadian masa lampau. Pengendalian atau penguasaan tersebut dapat melalui kepemilikan atau jenis perjanjian legal lainnya.

Secara umum ED PSAK 69 mengatur bahwa aset biologis atau produk agrikultur diakui saat memenuhi beberapa kriteria yang sama dengan kriteria pengakuan aset. Aset tersebut diukur pada saat pengakuan awal dan pada setiap akhir periode pelaporan keuangan pada nilai wajar dikurangi biaya untuk menjual. Keuntungan atau kerugian yang timbul dari perubahan nilai wajar aset diakui dalam laba rugi periode terjadinya. Pengecualian diberikan apabila nilai wajar secara jelas tidak dapat diukur secara andal.

Aset biologis seringkali secara fisik melekat pada tanah (sebagai contoh, pepohonan dalam hutan). Mungkin tidak terdapat pasar terpisah untuk aset biologis yang melekat pada tanah tersebut, namun mungkin saja terdapat pasar aktif untuk aset gabungan, yaitu, aset biologis, tanah yang belum dikembangkan, dan pengembangan tanah, sebagai suatu kesatuan. Entitas dapat menggunakan informasi mengenai aset gabungan untuk mengukur nilai wajar aset biologis. Sebagai contoh, nilai wajar tanah yang belum dikembangkan dan pengembangan tanah dapat dikurangkan dari nilai wajar aset gabungan untuk mendapatkan nilai wajar aset biologis.

\subsection{Pengakuan, Pengukuran, Pengungkapan dan Penyajian Aset Biologis}

Dalam IAS 41, entitas dapat mengakui aset biologis jika dan hanya jika :

a.perusahaan mengontrol aset tersebut sebagai hasil dari transaksi masa lalu;

b. memungkinkan diperolehnya manfaat ekonomi pada masa depan yang akan mengalir ke dalam perusahaan; dan

c.mempunyai nilai wajar atau biaya dari aset dapat diukur secara andal.

Aset biologis dalam laporan keuangan dapat diakui sebagai aset lancar maupun aset tidak lancar sesuai dengan jangka waktu transformasi biologis dari aset biologis yang bersangkutan.

Pengukuran aset biologis diatur dalam IAS 41. Aset biologis diukur berdasarkan nilai wajar. Aset biologis harus diukur pada pengakuan awal dan pada tanggal pelaporan berikutnya pada nilai wajar dikurangi estimasi biaya penjualannya, kecuali jika nilai wajar tidak bisa diukur secara andal. Metode yang paling dianjurkan adalah dengan menggunakan harga transaksi pasar paling kini atas aset biologis (mark-to-market) yang terdapat pada pasar aktif. Pasar aktif (active market) adalah pasar dimana item yang diperdagangkan homogen, setiap saat pembeli dan penjual dapat bertemu dalam kondisi normal dan dengan harga yang dapat dijangkau. Biaya penjualan terdiri atas komisi untuk perantara atau penyalur yang ditunjuk oleh pihak yang berwenang, serta pajak atau kewajiban yang dapat dipindahkan. Biaya transportasi serta biaya yang diperlukan untuk memasukkan barang ke dalam pasar tidak termasuk ke dalam biaya penjualan ini. Yang kedua, dapat pula menggunakan harga pasar aset yang sejenis (similar asset / sector bencmark) dengan aset biologis yang ingin dinilai penilaian ini dikenal dengan istilah market-determined prices. Yang ketiga, jika harga pasar tidak tersedia, standar yang ada menganjurkan untuk menggunakan model diskonto arus kas (discounted-cash flows model) yang biasa disebut mark-tomodel. Terakhir, apabila semua hal di atas tidak tersedia dan tidak dapat diukur secara andal, maka aset biologis harus diukur pada harga perolehannya dikurangi dengan akumulasi depresiasi dan pernurunan nilainya.

Keuntungan atau kerugian dari penilaian aset biologis dapat muncul pada pengakuan awal aset biologis yaitu sebesar selisih antara nilai perolehan awal aset biologis dengan nilai wajar aset biologis setelah dikurangi perkiraan biaya-biaya pada titik penjualan (estimated pointof- sale costs). Keuntungan atau kerugian terhadap penilaian aset biologis juga dapat muncul pada pengukuran setelah pengakuan 
awal, yaitu sebesar selisih antara nilai wajar terakhir aset biologis setelah dikurangi perkiraan biaya-biaya pada titik penjualan dengan nilai wajar aset biologis sebelumnya setelah dikurangi perkiraan biaya-biaya pada titik penjualan pada saat itu. Perubahan nilai wajar suatu aset biologis dapat disebabkan oleh pertumbuhan, kematian, produksi dan penghasilan yang menyebabkan perubahan-perubahan yang bersifat kualitatif dan kuantitatif, generasi aset yang baru atau tambahan aset biologis. Selain itu, perubahan nilai wajar aset biologis juga dapat disebabkan oleh perubahan pasar atau perekonomian di suatu negara. Perubahan-perubahan tersebut meliputi antara lain perubahan inflasi, nilai tukar mata uang, pertumbuhan ekonomi, permintaan, atau kebijakan pemerintah. Suatu entitas harus mengungkapkan jumlah keseluruhan keuntungan atau kerugian yang muncul pada pengakuan awal aset biologis dan produk agrikultur dan dari perubahan nilai wajar dikurangi dengan perkiraan biaya-biaya pada titik penjualan. Metode dan asumsi yang digunakan dalam menentukan nilai wajar juga harus diungkapkan. Nilai wajar dikurangi dengan perkiraan biaya-biaya pada titik penjualan terhadap produk agrikultur yang dipanen selama periode tersebut harus diungkapkan pada titik panen. Ketika nilai wajar tidak dapat diukur dengan andal, maka pengungkapan tambahan diperlukan.

Martani, et al (2012:290) menyatakan bahwa aset tetap disajikan di laporan posisi keuangan pada bagian aset tidak lancar. Aset biologis disajikan ke dalam aset lancar ketika masa manfaat/masa transformasi biologisnya kurang dari atau sampai dengan 1 (satu) tahun dan disajikan sebagai aset tidak lancar jika masa manfaat/masa transfomasi biologisnya lebih dari 1 (satu) tahun. Dalam ED PSAK No.69 entitas mengakui aset biologis atau produk agrikultur ketika, dan hanya ketika:

1. Entitas mengendalikan aset biologis sebagai akibat dari peristiwa masa lalu;

2. Besar kemungkinan manfaat ekonomik masa depan yang terkait dengan aset biologis tersebut akan mengalir ke entitas; dan

3. Nilai wajar atau biaya perolehan aset biologis dapat diukur secara andal.

Aset biologis diukur pada saat pengakuan awal dan pada setiap akhir periode pelaporan pada nilai wajar dikurangi biaya untuk menjual. Pengukuran nilai wajar aset biologis atau produk agrikultur dapat didukung dengan mengelompokkan aset biologis atau produk agrikultur sesuai dengan atribut yang signifi kan; sebagai contoh, berdasarkan usia atau kualitas. Entitas memilih atribut yang sesuai dengan atribut yang digunakan di pasar sebagai dasar penentuan harga.

Entitas mengungkapkan: (a) keberadaan dan jumlah tercatat aset biologis yang kepemilikannya dibatasi, dan jumlah tercatat aset biologis yang dijaminkan untuk liabilitas; (b) jumlah komitmen untuk pengembangan atau akuisisi aset biologis; dan (c) strategi manajemen risiko keuangan yang terkait dengan aktivitas agrikultur.

\subsection{Perbandingan Penggunaan Pendekatan Nilai Wajar dan Nilai Historis}

Charles Elad (2004) menyatakan bahwa IAS 41 dinilai kontroversial karena menampilkan perbedaan yang paling radikal dan menyeluruh dari akuntansi nilai historis, sehingga menimbulkan masalah-masalah teori dan praktek. Perbedaan ini antara lain dapat terlihat pada nilai aset, pendapatan dan laba perusahaan. Dia juga menyatakan bahwa penggunaan penilaian subjektif dalam memperkirakan nilai wajar, seperti harga pasar aset sejenis atau penggunaan model nilai sekarang, akan menghasilkan perlakuan yang berbeda yang akan menghambat komparabilitas dan harmonisasi.

Watts (2003) menyatakan bahwa pengukuran dengan menggunakan nilai wajar merupakan subyek manipulasi, oleh karena itu merupakan alat ukur yang lemah terhadap penilaian dan kinerja dibandingkan dengan penggunaan nilai historis. Dia menyatakan bahwa setiap usaha untuk melarang konservatisme akuntansi pasti akan gagal dan akuntansi tidak dapat bersaing dengan pasar dalam menilai suatu perusahaan (Watt, 2006).

Penttinen et al. (2004) menyatakan bahwa penerapan nilai wajar akan menyebabkan fluktuasi yang tidak realistis pada laba bersih perusahaan-perusahaan kehutanan. Sementara Herbohn dan Herbohn serta Dowling dan Godfrey (2001) menekankan adanya peningkatan volatilitas, manipulasi dan subyektifitas dari pendapatan yang dilaporkan berdasarkan nilai wajar. 


\subsection{Penelitian Terdahulu}

Farida (2013), dalam penelitiannya yang berjudul Analisis Perlakuan Akuntansi Aset Biologis Berdasarkan International Accounting Standard 41 Pada PT. Perkebunan Nusantara VII (Persero). Dalam penelitian ini menyimpulkan bahwa Aset biologis pada PTPN diakui sebagai persediaan dan dinilai berdasarkan nilai yang lebih rendah antara harga perolehan dan nilai realisasi bersih (net realizable value). Berbeda dengan IAS 41 yang pengakuannya juga menggunakan nilai wajar sebagai dasarnya. Selain itu Pengukuran Aset biologis berupa tanaman perkebunan pada PTPN VII (Persero) berdasarkan harga perolehan karena didasarkan pada pertimbangan bahwa nilai ini lebih terukur sehingga mampu memberikan informasi yang lebih andal. Pengukuran aset biologis pada PTPN VII (Persero) yang hanya berdasarkan harga perolehan dipandang belum mampu memberikan informasi yang relevan bagi pengguna laporan keuangan, karena nilai tersebut dianggap belum mampu menunjukkan informasi tentang nilai sebenarnya yang dimiliki oleh aset biologis. Dalam penelitian ini juga didapat bahwa Pencatatan Aset Biologis ke dalam jurnal dilakukan berdasarkan harga perolehan, belum menggunakan nilai wajar seperti pada ketentuan IAS 41. Penyajian Aset Biologis yaitu tanaman telah menghasilkan disajikan dengan nilai setelah dikurangi dengan akumulasi penyusutannya. Sedangkan produk agrikultur yang diakui sebagai persediaan disajikan dalam kelompok aset lancar (current asset), produk agrikultur yang siap dijual ditampilkan sebagai persediaan barang jadi dan produk agrikultur yang akan digunakan dalam proses produksi berikutnya ditampilkan sebagai persediaan bahan baku/pelengkap. Penelitian ini juga berkesimpulan bahwa Kurangnya peninjauan dan berbagai kesulitan yang dialami oleh perusahaan untuk mendapat informasi mengenai biaya-biaya yang berhubungan dengan aset biologis berupa tanaman perkebunan menyebabkan adanya kemungkinan aset biologis berupa tanaman perkebunan dapat disajikan lebih (under value) atau lebih tinggi (over value) dari yang seharusnya. Sehingga memungkinkan informasi mengenai aset biologis pada PTPN VII (Persero) masih kurang andal dan kurang relevan.

Maruli dan Mita (2010), dalam penelitiannya yang berjudul Analisis Pendekatan Nilai Wajar dan Nilai Historis Dalam Penilaian Aset Biologis Pada Perusahaan agrikultur: Tinjauan Kritis Rencana Adopsi IAS 41. Dalam penelitian ini tidak menemukan adanya perbedaan signifikan atas unsur laporan keuangan juga Penelitian ini tidak menunjukkan bahwa ada Perbedaan dalam hal praktek perataan laba yang dilakukan oleh perusahaan yang menerapkan nilai wajar. Secara keseluruhan, hasil penelitian ini menjelaskan bahwa tidak terdapat perbedaan yang signifikan pada nilai dan volatilitas aset, pendapatan, laba, ROA dan Income Smoothing Index (ISI) antara perusahaan-perusahaan agrikultur yang menggunakan pendekatan nilai wajar dengan yang menggunakan pendekatan nilai historis, serta tidak ditemukannya pengaruh yang berbeda antara penggunaan pendekatan nilai wajar dengan pendekatan nilai historis terhadap volatilitas earnings perusahaan.

Sari (2015) dalam penelitiannya yang berjudul Analisis Pengakuan, Pengukuran, Pengungkapan, Dan Penyajian Aset Biologis Berdasarkan Standar Akuntansi Keuangan Pada PT. Perkebunan Nusantara IX (Persero) menyimpulkan bahwa Aset biologis pada PT. Perkebunan Nusantara IX (Persero) diakui menjadi 2 (dua) yaitu aset tanaman semusim dan aset tanaman tahunan. Aset biologis pada PT. Perkebunan Nusantara IX (Persero) diukur berdasarkan harga perolehan karena dengan nilai ini lebih terukur sehingga menjadikan kualitas informasi laporan keuangan semakin baik dan relevan. Aset biologis pada PT. Perkebunan Nusantara IX (Persero) diungkapkan telah sesuai dengan Standar Akuntansi Keuangan. Perusahaan membuat rincian mengenai jenis dan jumlah aset biologis, metode penyusutan, umur manfaat dan tarif penyusutan, serta rekonsiliasi jumlah tercatat pada awal dan akhir periode. Aset biologis pada PT. Perkebunan Nusantara IX (Persero) disajikan pada laporan posisi keuangan dalam kelompok aset tidak lancar (non current asset) berupa tanaman menghasilkan dan tanaman belum menghasilkan.

\subsection{Jenis Penelitian}

\section{METODE PENELITIAN}

Penelitian ini selain menggunakan metode penelitian kualitatif menggunakan pendekatan analisis komparatif. Selain menjelaskan keadaan pada objek penelitian, penelitian juga ingin melihat dampak dari 
rencana penerapan ED PSAK No.69 tentang agrikultur jika diterapkan pada Daerah Likupang Selatan, bagaimana penerimaan petani daerah tersebut, dan bagaimana cara mereka beradaptasi dengan standar pelaporan yang baru.

\subsection{Metode Analisis}

Metode analisis yang digunakan adalah metode analisis deskriptif komparatif. Dalam Metode ini data yang diperoleh dianalisis secara kualitatif, yaitu dengan mengkaji, memaparkan, menelaah, dan menjelaskan data-data yang diperoleh untuk mendapatkan gambaran yang jelas dan menyeluruh tentang proses pengakuan dan pengukuran produk agrikultur berupa kelapa yang ada pada Desa di Daerah Likupang Selatan.

\subsection{Gambaran Umum Objek Penelitian}

IV. HASIL PENELITIAN DAN PEMBAHASAN

Daerah Likupang Selatan merupakan salah satu kecamatan di Minahasa Utara, Provinsi Sulawesi Utara. Sumber daya pertanian dan perkebunan dengan primadona tanaman kelapa terbesar di seluruh wilayah Minut sehingga merupakan usaha tani utama penduduk. Letak Geografisnya, membuat Daerah ini lebih tinggi suhunya dibandingkan dengan Daerah lain di Minahasa. Keadaan ini membuat, tumbuhan kelapa tumbuh subur dan cepat perkembangannya. Penduduk Daerah Likupang Selatan terkenal dengan hasil alam yaitu Kopra. Pembudidayaan tanaman kelapa, merupakan keterampilan dari penduduk Minahasa Utara. Semua bagian dari tanaman kelapa dapat dimanfaatkan. Oleh karena itu, tanaman kelapa menjadi komoditi utama daerah ini.

\subsection{Perlakuan Akuntansi Produk Agrikultur pada Desa di Kecamatan Likupang Selatan}

Petani Kopra pada Desa di Kecamatan Likupang Selatan menyusun laporan keuangannya dengan sistem tradisional. Sistem Tradisional, melakukan pengakuan produk agrikultur berdasarkan harga perolehan. Harga perolehan adalah semua biaya yang dikeluarkan untuk memperoleh aset tersebut mulai dari biaya pembelian hingga semua biaya-biaya yang timbul hingga aset tersebut siap dipergunakan. Sistem ini melakukan pencatatan secara manual. Pemrosesan data dengan sistem konvensional memerlukan waktu yang cukup lama. Sistem yang digunakan lebih sederhana yang tercermin dari dokumen yang ada dan belum sesuai acuan standar umum PSAK, pelaksanaan fungsi-fungsi terkait belum optimal dan penerapan pengendalian intern masih kurang.

Penyajian laporan keuangan umumnya hanya menyangkut laporan historis sehingga tidak dapat menggambarkan secara eksplisit prospek masa depan. Angka-angka akuntansi umumnya didasarkan pada hasil transaksi pertukaran sehingga hanya menggambarkan nilai pada saat itu. Laporan keuangan tidak menggambarkan likuiditas dan arus kas. Laporan yang digunakan bersifat umum, bukan melayani kepentingan khusus.

Laporan yang dikeluarkan menerapkan prinsip bahwa laba itu hanya ada ketika adanya jual-beli. Laporan keuangan pada Desa di kecamatan Likupang Selatan secara umum masih sangat sederhana dan perlu di sosialisasikan cara pencatatan dan pelaporan laporan keuangan yang benar, sehingga usaha-usaha yang ada boleh terus berlangsung dan terlaksana dengan benar dan lebih baik lagi kedepan.

Adapun laporan yang disajikan oleh petani Desa umumnya hanya sebatas laporan kas yang sederhana seperti jual beli, didalamnya termasuk biaya-biaya yang dikeluarkan untuk pemeliharaan, dan perhitungan untuk aset dan penyusutannya seringkali diabaikan. Pelaporan seperti ini harus diperbaiki. Aset biologis harus dicatat sebagai aset tidak lancar, dan harus diklasifikasikan menurut aset yang dikategorikan untuk kembangbiakan baik yang sudah menghasilkan maupun yang belum menghasilkan dan aset yang dikategorikan untuk dijual.

\subsection{Perlakuan Akuntansi Menurut ED PSAK No.69 tentang Agrikultur}

Aset biologis diukur pada saat pengakuan awal dan pada setiap akhir periode pelaporan pada nilai wajar dikurangi biaya untuk menjual. Pengukuran nilai wajar aset biologis atau produk agrikultur dapat 
didukung dengan mengelompokkan aset biologis atau produk agrikultur sesuai dengan atribut yang signifi kan; sebagai contoh, berdasarkan usia atau kualitas. Entitas memilih atribut yang sesuai dengan atribut yang digunakan di pasar sebagai dasar penentuan harga. Dalam seluruh kasus, entitas mengukur produk agrikultur pada titik panen pada nilai wajar setelah dikurangi biaya untuk menjual. Pernyataan ini mencerminkan pandangan bahwa nilai wajar produk agrikultur pada titik panen selalu dapat diukur secara andal.

Keuntungan atau kerugian yang timbul pada saat pengakuan awal aset biologis pada nilai wajar dikurangi biaya untuk menjual dan dari perubahan nilai wajar dikurangi biaya untuk menjual aset biologis dimasukkan dalam laba rugi pada periode dimana keuntungan atau kerugian tersebut terjadi. Kerugian mungkin timbul pada saat pengakuan awal aset biologis, karena biaya untuk menjual dikurangkan dalam menentukan nilai wajar dikurangi biaya untuk menjual aset biologis. Keuntungan mungkin timbul pada saat pengakuan awal aset biologis, seperti ketika anak sapi lahir. Keuntungan atau kerugian yang timbul pada saat pengakuan awal produk agrikultur pada nilai wajar dikurangi biaya untuk menjual dimasukkan dalam laba rugi pada periode dimana keuntungan atau kerugian tersebut terjadi. Keuntungan atau kerugian dapat timbul pada saat pengakuan awal produk agrikultur sebagai akibat dari hasil panen.

Aset biologis dapat diklasifi kasikan baik sebagai aset biologis menghasilkan maupun belum menghasilkan. Aset biologis menghasilkan adalah aset yang telah mencapai spesifi kasi untuk dipanen (untuk aset biologis yang dapat dikonsumsi) atau mampu menghasilkan panen yang berkelanjutan (untuk aset biologis produktif).

Entitas mengungkapkan: (a) keberadaan dan jumlah tercatat aset biologis yang kepemilikannya dibatasi, dan jumlah tercatat aset biologis yang dijaminkan untuk liabilitas; (b) jumlah komitmen untuk pengembangan atau akuisisi aset biologis; dan (c) strategi manajemen risiko keuangan yang terkait dengan aktivitas agrikultur.

Entitas menyajikan rekonsiliasi perubahan jumlah tercatat aset biologis antara awal dan akhir periode berjalan. Rekonsiliasitersebut mencakup: (a) keuntungan atau kerugian yang timbul dari perubahan nilai wajar dikurangi biaya untuk menjual; (b) kenaikan karena pembelian; (c) penurunan yang diatribusikan pada penjualan dan aset biologis yang diklasifikasikan sebagai dimiliki untuk dijual (atau termasuk dalam kelompok pelepasan yang diklasifikasikan sebagai dimiliki untuk dijual) sesuai dengan PSAK 58; (d) penurunan karena panen; (e) kenaikan yang dihasilkan dari kombinasi bisnis; (f) selisih kurs neto yang timbul dari penjabaran laporan keuangan ke mata uang penyajian yang berbeda, dan penjabaran dari kegiatan usaha luar negeri ke mata uang penyajian entitas pelapor; dan (g) perubahan lain.

Contoh laporan Posisi Keuangan Produk Agrikultur :

\begin{tabular}{|l|l|l|l|}
\hline PT. XX & Catatan & 31 Desember & 31 Desember \\
\hline Laporan Posisi Keuangan & & $\mathbf{2 0 x 1}$ & $\mathbf{2 0 x 0}$ \\
\hline ASET & \multicolumn{3}{l|}{} \\
\hline Aset Lancar & \multicolumn{2}{|l|}{} \\
\hline Kas & 10.000 & 10.000 \\
\hline Piutang Usaha dan Piutang Lain-lain & & 88.000 & 65.000 \\
\hline Persediaan & & 82.950 & 70.650 \\
\hline Total Aset Lancar & & $\mathbf{1 8 0 . 9 5 0}$ & $\mathbf{1 4 5 . 6 5 0}$ \\
\hline Aset tidak lancer & \multicolumn{3}{|l|}{} \\
\hline Aset biologis-belum menghasilkan & 52.060 & 47.730 \\
\hline Aset biologis -menghasilkan & & 372.990 & 411.840 \\
\hline Subtotal-aset biologis & 425.050 & 459.570 \\
\hline Aset tetap & 1.462 .650 & 1.409 .800 \\
\hline Total Aset tidak lancar & $\mathbf{1 . 8 8 7 . 7 0 0}$ & $\mathbf{1 . 8 6 9 . 3 7 0}$ \\
\hline Total Aset & $\mathbf{2 . 0 6 8 . 6 5 0}$ & $\mathbf{2 . 0 1 5 . 0 2 0}$ \\
\hline
\end{tabular}


Ekuitas dan Liabilitas

\begin{tabular}{|l|l|l|}
\hline \multicolumn{2}{|l|}{ Liabilitas Jangka Pendek } & 150.020 \\
\hline Utang Usaha dan Utang Lain-lain & 165.822 & $\mathbf{1 5 0 . 0 2 0}$ \\
\hline Total Liabilitas Jangka Pendek & $\mathbf{1 6 5 . 8 2 2}$ & 1.000 .000 \\
\hline Ekuitas & 1.000 .000 & 865.000 \\
\hline Modal Saham & 902.828 & $\mathbf{1 . 8 6 5 . 0 0 0}$ \\
\hline Saldo Laba & $\mathbf{1 . 9 0 2 . 8 2 8}$ & $\mathbf{2 . 0 1 5 . 0 2 0}$ \\
\hline Total Ekuitas & $\mathbf{2 . 0 6 8 . 6 5 0}$ & \\
\hline Total Ekuitas dan Liabilitas &
\end{tabular}

\section{Laporan Penghasilan Komprehensif Lain}

\begin{tabular}{|l|l|l|}
\hline PT. XX & Catatan & $\begin{array}{l}\text { Untuk Tahun yang Berakhir 31 } \\
\text { Desember 20x1 }\end{array}$ \\
\hline Laporan Penghasilan Komprehensif & 518.240 \\
\hline Nilai Wajar produk yang diproduksi & 39.930 \\
\hline $\begin{array}{l}\text { Keuntungan yang timbul dari perubahan nilai wajar } \\
\text { dikurangi biaya untuk menjual aset biologis }\end{array}$ & $\mathbf{5 5 8 . 1 7 0}$ \\
\hline & & $(137.523)$ \\
\hline Persediaan yang digunakan & $(127.283)$ \\
\hline Biaya Pegawai & $(15.250)$ \\
\hline Biaya Penyusutan & $(197.092)$ \\
\hline Beban Operasi lain & $\mathbf{( 4 7 7 . 1 4 8 )}$ \\
\hline & $\mathbf{8 1 . 0 2 2}$ \\
\hline Laba Operasi & $\mathbf{( 4 3 . 1 9 4 )}$ \\
\hline Pajak Penghasilan & $\mathbf{3 7 . 8 2 8}$ \\
\hline Penghasilan Komprehensif tahun berjalan & \\
\hline
\end{tabular}

Laporan Perubahan Ekuitas

\begin{tabular}{|l|l|l|l|}
\hline PT.XX & & \multicolumn{2}{|l|}{$\begin{array}{l}\text { Untuk Tahun yg Berakhir 31 } \\
\text { Desember 20x1 }\end{array}$} \\
\hline Laporan Perubahan Ekuitas & & & \\
\hline & Modal Saham & Saldo Laba & Total \\
\hline Saldo per Januari 20x1 & 1.000 .000 & 865.000 & 1.865 .000 \\
\hline Penghasilan Komprehensif tahun berjalan & & 37.828 & 37.828 \\
\hline Saldo per 31 Desember 20x1 & $\mathbf{1 . 0 0 0 . 0 0 0}$ & $\mathbf{9 0 2 . 8 2 8}$ & $\mathbf{1 . 9 0 2 . 8 2 8}$ \\
\hline
\end{tabular}


Laporan Arus Kas

\begin{tabular}{|l|l|l|}
\hline PT.XX & Catatan & $\begin{array}{l}\text { Untuk Tahun yg Berakhir 31 } \\
\text { Desember 20x1 }\end{array}$ \\
\hline Laporan Arus Kas & & \\
\hline Arus kas dari Aktivitas Operasi & 498.027 \\
\hline Penerimaan kas dari penjualan produk agrikultur & 97.913 \\
\hline Penerimaan Kas dari penjualan aset biologis & $(460.831)$ \\
\hline Pembayaran kas untuk perlengkapan dan karyawan & $(23.815)$ \\
\hline Pembayaran kas untuk pembelian ternak sapi perah & $\mathbf{1 1 1 . 2 9 4}$ \\
\hline & $(43.194)$ \\
\hline Pajak Penghasilan & $\mathbf{6 8 . 1 0 0}$ \\
\hline Kas Neto dari Aktivitas Operasi & \\
\hline Arus kas dari aktivitas Investasi & $(68.100)$ \\
\hline Pembelian Aset tetap & $\mathbf{6 8 . 1 0 0 )}$ \\
\hline Kas Neto yang digunakan untuk aktivitas investasi & $\mathbf{0}$ \\
\hline Kenaikan neto kas & $\mathbf{1 0 . 0 0 0}$ \\
\hline Kas pada awal periode & $\mathbf{1 0 . 0 0 0}$ \\
\hline Kas pada Akhir periode & & \\
\hline
\end{tabular}

Dampak yang akan ditimbulkan PSAK No.69 tentang agrikultur adalah kesalahan pada pengakuan nilai wajar, petani mungkin sulit dalam penentuan nilai wajar jika tidak ada dasar perhitungan yan diberikan. Dan kemungkinan yang terjadi berikut adalah terjadinya perataan laba atau manipulasi nilai pengakuan atas aset. Dan hal ini bisa berdampak pada pelaporan yang tidak benar. Namun hal ini seharusnya dapat dihindari karena nilai wajar menawarkan kemudahan dibandingkan dengan menerapkan biaya historis.

Dengan menerapkan ED PSAK No.69 tentang agrikultur maka petani/pengusaha tanaman kelapa akan merasakan manfaat seperti kelangsungan usaha mereka kedepan sehingga boleh bersaing dengan pasar Global. Dengan adanya pelaporan menurut SAK yang baru yang nantinya akan diterapkan pada 2017, maka petani memiliki gambaran yang benar tentang aset yang mereka miliki.

\subsection{Kesimpulan}

\section{PENUTUP}

Desa di Daerah Likupang Selatan masih melakukan pencatatan dan pelaporan keuangan dengan sistem konvensional. Pencatatan yang dilakukan sangat sederhana hanya menyangkut jual beli termasuk didalamnya biaya-biaya yang dikeluarkan untuk pemeliharaan terhadap aset biologis tersebut.

Penyajian laporan keuangan umumnya hanya menyangkut laporan historis sehingga tidak dapat menggambarkan secara eksplisit prospek masa depan. Angka-angka akuntansi umumnya didasarkan pada hasil transaksi pertukaran sehingga hanya menggambarkan nilai pada saat itu.

\subsection{Saran}

Pengusaha kelapa di Desa Daerah Likupang Selatan, dapat menerapkan pencatatan dan pelaporan menurut ED PSAK No.69, namum agar supaya berhasil, sebelum penerapan pada tahun 2017, sebaiknya harus dilakukan sosialisasi penerapan PSAK No.69 yang baru dan juga SAK-ETAP dan manfaat yang akan didapatkan dengan adanya penerapan tersebut.

\section{DAFTAR PUSTAKA}

Accounting Principles Board. 1970. APB Statement No.4 Basic Concepts and Accounting Principles Underlying Financial Statement of Business Enterprises. AICPA.

Baridman, Zaki. 1986. Intermediate Accounting Theory. Edisi alih bahasa. Yogyakarta: AK Group. 
Dewan Standar Akuntansi Keuangan. 2015. Exposure Draft PSAK No.69 tentang Agrikultur. Jakarta.

Farida, Ike. 2013. Analisis perlakuan akuntansi Aset biologis berdasarkan IAS 41 pada PT.Perkebunan Nusantara VII (Persero). Universitas Negeri Surabaya. Surabaya.

Financial Accountig Standards Boards 1984. Statement of Financial Accounting Concepts No.3. Stamford. Connecticut.

Ikatan Akuntan Indonesia. 2015. Standar Akuntansi Keuangan. Jakarta: Salemba Empat.

International Accounting Standard Committee (IASC). 2000. International Accounting Standard No.41, Agriculture.

Kieso, Donald E., Jerry J. Weygandt, and Terry D. Warfield. 1998. Intermediate Accounting. 9th Ed. New York: John Willey \& Sons, Inc.

Damba Satria, Dandy. 2008. Perlakuan Akuntansi Atas Aktiva Biologis dan Penyajiannya dalam Laporan Keuangan Perusahaan. Surabaya: Universitas Airlangga.

Belkauoi dan Riahi, Ahmed. 2004. Accounting Theory. Jakarta: Salemba Empat.

Ahmed, A.S and Takeda, C. (1995) "Stock market valuation of gains and losses on commercial banks' investment securities. An empirical analysis". Journal of Accounting and Economics, 20, p. 207225.

Argiles, Joseph M, et al., ed. "Fair Value versus Historic Cost Valuation for Biological Assets: Implication for the Quality of Financial Information." Documents De Treball, De La Facultat D’Economia I Empresa (2009): 1-16.

Barth, M.E. (1994) "Fair value accounting and the management of the firm". Critical Perspectives on Accounting, 14, p. 383-415.

Bleck, A. and Liu, X. (2007) "Market transparency and the accounting regime". Journal of Accounting Research, 45(2), p. 229-256.

Choy, A.K. (2006) "Fair value as a relevant metric: a theoretical investigation" Available at SSRN: http://ssrn.com/abstract $=878119$

Danbolt, J. and Rees, W. (2008) “An experiment in fair value accounting: UK investment vehicles". European Accounting Review, 17(2), p. 271-303.

Donald E Kieso, Weygandt, and Warfield. Intermediate Accounting, Twelfth edition, USA: John Willey \& Son, Inc, 2007.

Elad, Ch. (2004) "Fair Value accounting in the agricultural sector: some implication from the international accounting harmonization”. European Accounting Review, 13(4), p. 621-641.

Herborhn, K. and Herbohn, J. (2006) "International Accounting Standard (IAS) 41: what are the implications for reporting forest assets?". Small-scale Forest Economics, Management and Policy, 5(2), p. $175-189$

Hongren, Datar \& Foster. Cost Accounting, A Managerial Emphasis, 11th Edition, New Jersey: Pearson Education, Inc., 2003.

Iniguez, R. and Poveda, F. (2004) "Long-run abnormal returns and income smoothing in the Spanish stock market", European Accounting Review, 13(1), p. 105-130

Maruli, Saur., Mita, Aria Farah. 2010. Analisis pendekatan Nilai wajar dan nilai Historis dalam Penilaian Aset Biologis pada Perusahaan Agrikultur : Tinjauan Kritis Rencana Adopsi IAS 41. Universitas Indonesia. SNA XIII Purwekerto.

Mulyono, Sri. Statistika Untuk Ekonomi Edisi Kedua, Jakarta: Lembaga Penerbit Fakultas Ekonomi, Universitas Indonesia, 2003. 
Nachrowi, D Nachrowi, Hardius Usman. Pendekatan Populer dan Praktis Ekonometrika Untuk Analisis Ekonomi dan Keuangan, Jakarta: Lembaga Penerbit Fakultas Ekonomi, Universitas Indonesia, 2006.

Nastiti, Desti Harum Dewi. 2014. Deplesi Aset Biologis pada Peternakan Sapi Perah KUD Kota Boyolali. Universitas Dian Nuswantoro.

Sari, Ana Yuwanita. 2015. Analisis pengakuan, Pengukuran, pengungkapan dan Penyajian Aset Biologis berdasarkan Standar Akuntansi Keuangan pada PT. Perkebunan Nusantara IX (Persero). Universitas Muhammadiyah Surakarta.

Schroeder, Richard G, Myrtle W, Jack M. Financial Accounting Theory and Analysis: Text and Cases, 9th Editon, USA: John Willey \& Son, Inc, 2009.

Plantin, G. and Sapra, H. (2008) “Marking-to-market: panacea or Pandora's box?”. Journal of Accounting Research, 46, p. 435-436.

Ronen, J. (2008) "To fair value or not to fair value: a broader perspective", Abacus, 44(2), p. 181-208.

Sekaran, Uma. Research Methods for Business, 4th Edition, USA: John Willey \& Son, Inc, 2003.

Svensson, Anders, et al., ed. "The Swedish Forest Industry's Application of the IAS 41 - Agriculture." Master's Thesis, Stockholm School of Economics (2008): 4-16.

Watts, R.L (2006) "What has the invisible hand achieved?". Accounting and Business Research, 36(special issue), 51-61.

Winarno, Wing Wahyu. Analisis Ekonometrika dan Statistika dengan Eview, Edisi Kedua, Yogyakarta: Unit Penerbit dan Percetakan Sekolah Tinggi Ilmu Manajemen YKPN, 2009. 